\title{
Immune response in piglets orally immunized with recombinant Bacillus subtilis expressing the capsid protein of porcine circovirus type 2
}

\author{
Shuai Zhang, Chunxiao Mou, Yanan Cao, En Zhang and Qian Yang*
}

\begin{abstract}
Background: Porcine circovirus type 2 (PCV2) is the causative agent of postweaning multisystemic wasting syndrome, and is associated with a number of other diseases. PCV2 is widely distributed in most developed swine industries, and is a severe economic burden. With an eye to developing an effective, safe, and convenient vaccine against PCV2-associated diseases, we have constructed a recombinant Bacillus subtilis strain (B. subtilis-Cap) that expresses the PCV2 capsid protein (Cap).

Methods: Electroporation of a plasmid shuttle vector encoding the PCV2 Cap sequence was use to transform Bacillus subtilis. Flow cytometry was used to evaluate in vitro bone marrow derived dendritic cell (BM-DC) maturation and T cell proliferation induced by B. subtilis-Cap. Orally inoculated piglets were used for in vivo experiments; ELISA and western blotting were used to evaluate B. subtilis-Cap induced PCV2-specific IgA and IgG levels, as well as the secretion of cytokines and the expression of Toll-like receptor 2 (TLR2) and Toll-like receptor 9 (TLR9).

Results: We evaluated the immune response to B. subtilis-Cap in vitro using mouse BM-DCs and in vivo using neonatal piglets orally inoculated with B. subtilis-Cap. Our results showed that the recombinant $B$. subtilis-Cap activated BM-DCs, significantly increased co-stimulatory molecules (CD40 and CD80) and major histocompatibility complex II, and induced allogenic T cells proliferation. Piglets immunized with B. subtilis-Cap had elevated levels of PCV2specific IgA in the mucosal tissues of the digestive and respiratory tract, and PCV2-specific lgG in serum $(P<0.05$ or $P<$ 0.01). Ileal immunocompetent cells, such as the IgA-secreting cells $(P<0.01)$, intestinal intraepithelial lymphocytes (IELs) $(P<0.01), \mathrm{CD}^{+}$T lymphocytes $(P<0.01)$ and $\mathrm{CD} 4^{+}$T lymphocytes $(P<0.01)$ increased significantly in the $B$. subtilis-Cap immunized piglets. Additionally, $B$. subtilis-Cap inoculation resulted in increased the expression of TLR2 and TLR9 $(P<0.01)$, and induced the secretion of cytokines $I L-1 \beta, I L-6$, interferon- $\gamma$, and $\beta$-defensin $2(P<0.01)$.

Conclusions: We constructed a prototype PCV2 vaccine that can be administered orally and elicits a more robust humoral and cellular immunity than inactivated PCV2. B. subtilis-Cap is a promising vaccine candidate that is safe, convenient, and inexpensive. Further in vivo research is needed to determine its full range of efficacy in pigs.
\end{abstract}

Keywords: Bacillus subtilis WB800N, Porcine circovirus type 2 (PCV2), Capsid protein, Dendritic cells, Neonatal piglets, Immune responses

\footnotetext{
* Correspondence: zxbyq@njau.edu.cn

MOE Joint International Research Laboratory of Animal Health and Food

Safety, College of Veterinary Medicine, Nanjing Agricultural University, Wei

gang 1, Nanjing, Jiangsu 210095, People's Republic of China
}

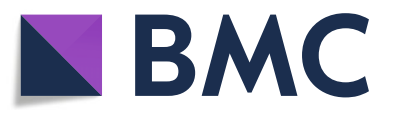

(c) The Author(s). 2020 Open Access This article is distributed under the terms of the Creative Commons Attribution 4.0 International License (http://creativecommons.org/licenses/by/4.0/), which permits unrestricted use, distribution, and reproduction in any medium, provided you give appropriate credit to the original author(s) and the source, provide a link to the Creative Commons license, and indicate if changes were made. The Creative Commons Public Domain Dedication waiver (http://creativecommons.org/publicdomain/zero/1.0/) applies to the data made available in this article, unless otherwise stated. 


\section{Background}

Porcine circovirus (PCV) is a member of the genus Circovirus in the family Circoviridae [1]. Currently three genotypes of PCV are recognized: types 1,2, and 3. PCV2 is a small (about $17 \mathrm{~nm}$ ), icosahedral, nonenveloped virus containing a single-stranded negative sense DNA genome [2]. The DNA is approximately 1700 nucleotides and includes two open reading frames (ORFs) [3-5]. ORF1 encodes two replicationassociated proteins (Rep and Rep') and ORF 2 encodes the viral capsid protein (Cap). Cap is the principal immunogenic protein available for the induction of PCVneutralizing antibodies [6-8]. PCV2 is the causative agent of postweaning multisystemic wasting syndrome (PMWS) [9-11]. It is widely distributed in most of the world's swine populations and may have an association with other porcine circovirus associated diseases (PCVAD) [12], such as porcine respiratory disease complex (PRDC), porcine dermatitis and nephropathy syndrome (PDNS), reproductive failure, and congenital tremors [13-16]. PCV2 preferentially resides in immune cells, such as macrophages and dendritic cells, and impairs their function. PCV2 infection usually accompanies lymphocyte or monocyte depletion which causes further immune suppression [17, 18]. Particularly in piglets, the immunosuppression caused by PCV2 often results in concurrent infection with other pathogens, such as porcine reproductive respiratory syndrome virus (PRRSV), porcine parvovirus (PPV), Haemophilus parasuis, or Mycoplasma hyopneumoniae. Together, these PCV-associated diseases impose an enormous economic burden on swine industries across the world $[19,20]$.

PCV2 infection may initially occur on mucosal surfaces, especially the respiratory or intestinal tract [21-24]. However, the vaccines now available cannot effectively induce mucosal immunity against PCV2 infection when administered parenterally. Commercial PCV2 vaccines (delivered intramuscularly) that include inactivated whole PCV2 virus, a subunit of open reading frame 2 , or inactivated chimeric PCV1-2, can reduce clinical signs and increase production parameters in farms with PMWS [25-28]. However, these vaccines do not prevent the infection or transmission of PCV2 completely [25]. In addition, intramuscular injection involves laborious and timeconsuming procedures, causes inflammatory responses, and risks management-derived stress reactions that hamper animal growth and degrade meat quality [29]. There is an urgent need for a safe and efficient PCV2 vaccine that is both convenient to administer and inexpensive. Compared with traditional vaccines, mucosal vaccines are administered orally or intranasally, cause less stress, and stimulate effective mucosal immune responses [30-32]. It would therefore be highly desirable to develop a PCV2 vaccine that is delivered without injection and is able to induce mucosal immune responses.

Bacillus subtilis (B. subtilis) is a non-pathogenic grampositive bacterium that has been used as an additive to improve the growth performance and the feed conversion ratio in animals [33-35]. It has also been widely used as a probiotic bacterium to induce non-specific immune responses against infection, such as increasing IgA production and regulating the balance of the Th1 and Th2 pathways [36, 37]. Lysozyme, phospholipase A and other enzymes found in the saliva along with intestinal proteases, pepsin, and the highly acidic gastric environment $(\mathrm{pH} 1-2)$ present a particularly harsh environment for orally administered vaccines [38], such as the inactivated PCV2. The ability of $B$. subtilis to survive under extreme conditions, such as high temperatures, desiccation, and exposure to noxious chemicals [39], and $B$. subtilis is highly stable and ismable to withstand the chemical and enzymatic conditions of the intestinal tract, which makes it attractive as a therapeutic molecule and oral vaccine vehicle for delivery of immunogens to intestinal mucosa [40, 41].

In this study, we used B. subtilis WB800N to construct a recombinant bacterial strain that expressed the Cap protein of PCV2 virus. To determine if the recombinant can be used as an effective oral mucosal vaccine, we administered it orally to piglets and then tested their local mucosal and systemic immune responses.

\section{Methods}

\section{Bacteria, plasmids, virus, and animals}

B. subtilis WB800N and the pHT43 expression vector [42] (E. coli-B. subtilis shuttle vector) used to express recombinant proteins in B. subtilis were kindly provided by Dr. Xuewen Gao. The pMD-19 T-Cap cloning vector was previously constructed in our laboratory.

Porcine circovirus 2 strain DBN-SX07-2 (GenBank: HM641752.1) was kindly provided by Dr. Ping Jiang, propagated on porcine kidney (PK) 15 cells, and stored at $-70{ }^{\circ} \mathrm{C}$. Virus cultures were filtered through a $0.22 \mu \mathrm{m}$ filter, and concentrated by ultra-centrifugation at $10,000 \times \mathrm{g}$ for $2.5 \mathrm{~h}$, then purified on a discontinuous sucrose density gradient at $10,000 \times \mathrm{g}$ for $2.5 \mathrm{~h}$. The purified PCV2 was inactivated by exposure to ultraviolet light for $4 \mathrm{~h}$ then tested for complete loss of infectivity by inoculation onto PK15 cells which were subsequently passaged 3 times. Purified virus concentrations were measured by BCA protein assay.

4-week-old male C57BL/6 mice were obtained from the Animal Research Center of Yangzhou University (Yangzhou, China). Twenty-four Duroc Landrace Yorkshire piglets, obtained from healthy primiparous sows free from TGEV, PEDV, PCV2, and PRRSV, were isolated from the 
sows at birth and fed artificial milk, containing no maternally derived antibodies. At 5 days of age they were divided into four groups and maintained in separate rooms. The animal studies were approved by the Institutional Animal Care and Use Committee of Nanjing Agricultural University (Nanjing, China) and followed the National Institutes of Health's guidelines for the performance of animal experiments.

\section{Reagents and antibodies}

Plasmid isolation and gel elution kits were purchased from Axygen Biosciences (Union City, CA, USA). DNA size markers were purchased from Novoprotein (DM028-01A). DNA polymerase and Taq polymerase were purchased from TaKaRa Biotechnology Corporation (Dalian, Japan). Restriction enzymes were purchased from New England Biolabs (England). ClonExpress II one step cloning kit (Vazyme). DNA used in the experiments was quantified using a NanoDrop 2000 spectrophotometer (Thermo Scientific USA). The antibiotics and the concentrations used in culturing B. subtilis were kanamycin $(50 \mu \mathrm{g} / \mathrm{ml})$, chloromycetin $(15 \mu \mathrm{g} / \mathrm{ml})$, ampicillin $(100 \mu \mathrm{g} / \mathrm{ml})$, isopropy$\beta$-D-thiogalactopyranoside (IPTG $0.1 \mathrm{mM}$ ). RPMI 1640 medium, penicillin and streptomycin were purchased from Invitrogen (Grand Island, NY, USA). Fetal bovine serum (GIBCO), recombinant GM-CSF (granulocyte-macrophage colony-stimulating factor), and IL-4 were purchased from PeproTech (Rocky Hill, NJ). LPS (from E. coli 026:B6) was obtained from Sigma-Aldrich (St Louis, MO, USA). Red blood cell lysing buffer (Beyotime, China). T cell isolation kit (Miltenyi Biotech, Germany). RIPA lysis buffer and SDS-PAGE sample loading buffer $(5 x)$ were obtained from FcMACS (Nanjing, China). The BCA protein assay kit was obtained from Thermo Scientific (USA).

Fluorescent-labeled anti-mouse mAbs CD40-FITC, CD80-FITC, and MHC II-FITC were used for flow cytometry and were purchased from eBioscience (San Diego, CA, USA). Mouse anti-Cap mAbs were kindly provided by Dr. Ping Jiang [43]. Dylight 488 goat antimouse IgG $(\mathrm{H}+\mathrm{L})$ (MultiSciences (Lianke) Biotech, CO., LTD). The florescent dye carboxyfluorescein succinimidyl ester (CFSE) was obtained from Invitrogen (Grand Island, NY, USA). Rabbit anti-pig CD3 (SP7) mAbs was purchased from Abcam (Hongkong). FITC rabbit anti-pig CD4a was purchased from Santa Cruz Biotech. Mouse anti-pig CD8 alpha antibody (76-2-11) was purchased from Novus. SABC-POD (rabbit and mouse IgG) kits and peroxidase substrate kits were purchased from BOSTER (Wuhan, China). Rabbit antihuman TLR2 and TLR9 polyclonal antibodies were purchased from Thermo Scientific USA. Rabbit antiGAPDH and goat anti-rabbit IgG-HRP were from BioWorld Technology, Inc. (St. Louis Park, MN, USA). Enhanced chemiluminescence reagents were purchased from New Cell \& Molecular Biotech Co., Ltd. (China). Mouse PCV2 IgA and IgG ELISA kits, porcine PCV2 IgA and IgG ELISA kits, the porcine interleukin 6 (IL-6) ELISA kit, the porcine interleukin 10 (IL-10) ELISA kit, and the porcine interferon- $\gamma$ (IFN- $\gamma$ ) ELISA kit were purchased from SenBeijia Biological Technology Co., Ltd. (Nanjing, China). The pig IL-1 beta ELISA kit (ab 100,754) and the pig TNF alpha ELISA kit (ab 100,756) were acquired from Abcam (Hongkong). The porcine defensin beta 2 (DEFb2) ELISA kit was purchased from Bio-Swamp.

\section{Construction of pHT43-cap and recombinant $B$. subtilis-cap strains}

To obtain a recombinant strain of B. subtilis WB800N with the ability to express PCV2 Cap protein, the plasmid shuttle vector pHT43-Cap was constructed (Fig. 1). First, the PCV2 Cap sequence (702 bp, GenBank accession number ADM16685.1) was amplified from pMD-19 T-Cap using the primers F:5' -tcagccgtaggatccatgacgtatccaagg-3' (BamHI site is underlined) and R: $5^{\prime}$-ggcgggctgccccgggttagggtttaagtg3' (SmaI site is underlined). The E. coli-B. subtilis shuttle vector pHT43 was prepared for use by digestion with BamHI and SmaI. The Cap amplicon was purified, digested with BamHI and Smal, then inserted downstream of the Pgrac promoter region in pHT43 using a ClonExpress II one step cloning kit to generate the recombinant pHT43Cap shuttle vector in E. coli DH5a cells (Fig. 1a). The structure of pHT43-Cap was confirmed by DNA sequencing (Sangon Biotech).

The pHT43 vector (control) and the pHT43-Cap recombinant plasmid were transformed into $B$. subtilis by electroporation as previously described $[42,44]$. The transformed strains were designated $B$. subtilis and $B$. subtilis-Cap, respectively. Briefly, $50 \mathrm{ng}$ of recombinant pHT43-Cap plasmid was gently mixed with $60 \mu \mathrm{L}$ of competent $B$. subtilis for $1 \mathrm{~min}$ at $4{ }^{\circ} \mathrm{C}$. The mixture was transferred into a pre-cooled electroporation cuvette (inter-electrode distance of $0.1 \mathrm{~cm}$ ) (Bio-Rad, Hercules, CA, USA) and subjected to a single electric pulse $(22 \mathrm{KV} / \mathrm{cm}$, $25 \mu \mathrm{F}, 200 \Omega$ ). The cells were then cultured overnight at $37^{\circ} \mathrm{C}$, and positive colonies were selected based on growth on $15 \mu \mathrm{g} / \mathrm{mL}$ chloramphenicol antibiotic agar Luria-Bertani (LB) plates $(10 \mathrm{~g} / \mathrm{L}$ tryptone, $5 \mathrm{~g} / \mathrm{L}$ yeast extract, $10 \mathrm{~g} / \mathrm{L} \mathrm{NaCl}$, and $20 \mathrm{~g} / \mathrm{L}$ agar).

\section{Expression of cap protein by the recombinant $B$. subtilis}

To detect expression of the Cap protein, a single transformed colony was inoculated into LB medium containing chloramphenicol $(15 \mu \mathrm{g} / \mathrm{mL})$ and incubated overnight at $37^{\circ} \mathrm{C}$ with agitation at $180 \mathrm{rpm}$. Fresh LB medium $(100 \mathrm{ml})$ was inoculated with the overnight culture, to an initial cell density $\left(\mathrm{OD}_{600}\right)$ of 0.1 . Pgrac in pHT43 is derived from a fusion between the strong 

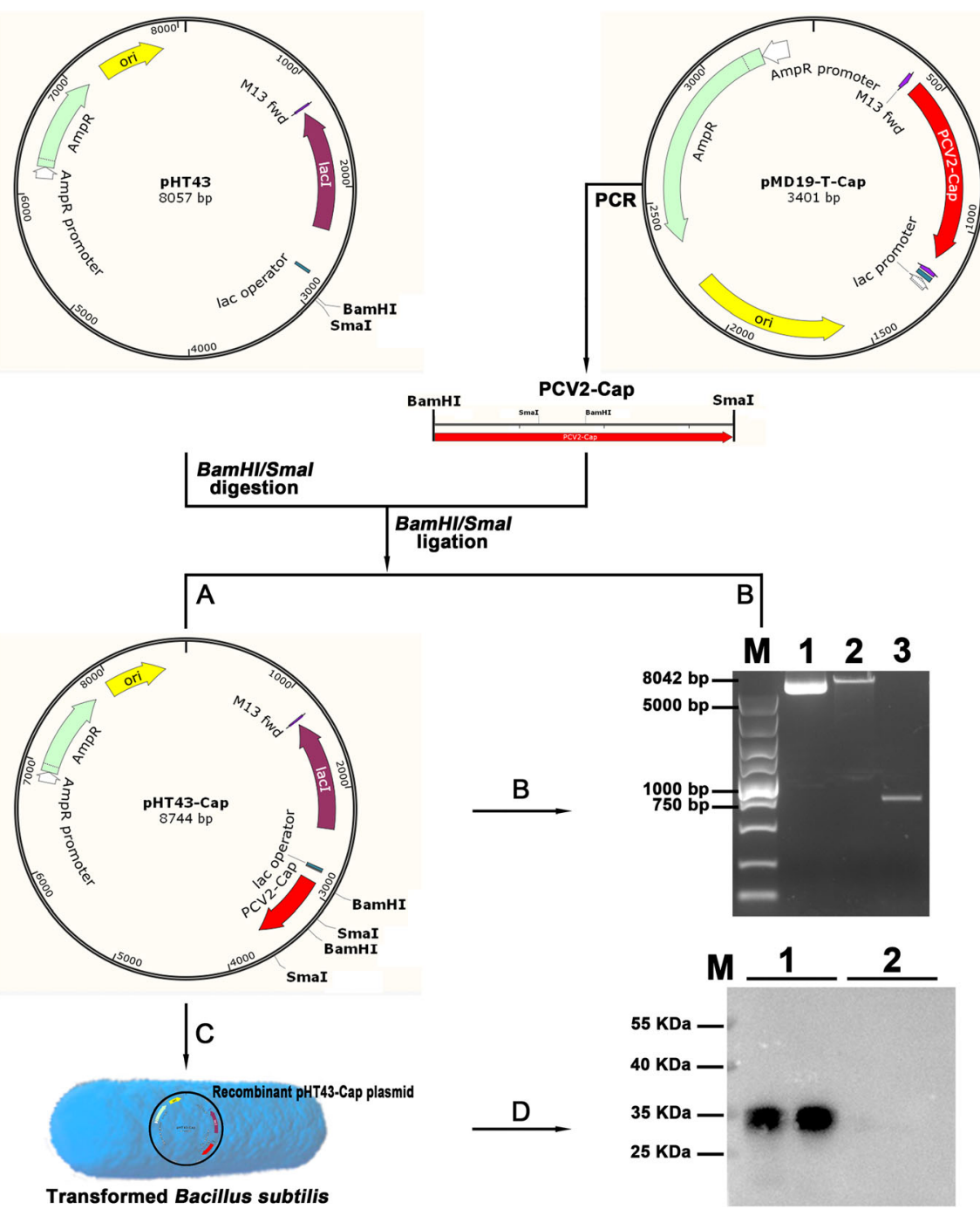

Fig. 1 Schematic of pHT43-Cap construction and protein expression. a The Cap sequence was amplified from pMD19-T-Cap, and inserted into pHT43 between the BamHI and Smal sites, generating plasmid pHT43-Cap. b Agarose gel of pHT43-Cap, pHT43, and Cap fragment amplified from pMD19-T-Cap in lanes 1, 2, and 3 respectively. Plasmids were digested with BamHl and Smal before electrophoresis. Lane M is a 5000 bp DNA ladder. c pHT43 (vector control) and pHT43-Cap recombinant plasmids were transformed into B. subtilis by electroporation. $\mathbf{d}$ Western blotting analysis of the PCV2 Cap protein expressed in B. subtilis-Cap, lanes 1. Extracts of B. subtilis (transfected with pHT43) were run in lanes 2, and lane $\mathrm{M}$ is protein molecular weight ladder

promoter that precedes the groESL operon of Bacillus subtilis and the lac operator, enabling the IPTGinducible expression of downstream genes. When the culture reached log-phase $\left(\mathrm{OD}_{600} 0.7-0.8\right)$, IPTG was added to $0.1 \mathrm{mM}[45]$ and then incubated for $8 \mathrm{~h}$. The bacteria were collected by centrifugation at $3000 \times \mathrm{g}$ for $10 \mathrm{~min}$ at $4{ }^{\circ} \mathrm{C}$, and cells were disrupted by sonication. For immunodetection of the heterologous Cap protein, western blots were prepared and incubated with mouse anti-Cap specific antibody (1:1000), followed by horseradish peroxidase (HRP)-conjugated rabbit anti-mouse IgG (1:5000). Binding was detected using enhanced chemiluminescence.

\section{Preparation of recombinant $B$. subtilis for immunization}

The recombinant $B$. subtilis-Cap and corresponding empty plasmid control (B. subtilis-pHT43) were cultured in LB medium or on LB plates fortified with $1.5 \%$ agar and appropriate antibiotic at $37^{\circ} \mathrm{C}$. Bacterial cultures were centrifuged at $3000 \times g$ for $10 \mathrm{~min}$ at $4{ }^{\circ} \mathrm{C}$ and washed three times with sterile phosphate-buffered saline (PBS). For use in oral immunization, the washed pellets were resuspended to $1 \times 10^{10} \mathrm{CFU} / \mathrm{ml}$ in sterile PBS supplemented with $1 \%$ sucrose. Bacterial titers (colony forming units or CFU) were determined by plate counts. Successive dilutions (the values of CFU between 30 and 300) of each strain were selected for calculation. 


\section{Isolation and culture of mouse bone marrow derived dendritic cells}

Bone marrow derived dendritic cells (BM-DCs) were generated as previously reported [46]. Briefly, bone marrow cells were flushed from the tibias and femurs of 4-week old C57BL/6 mice, treated with red blood cell lysing buffer and cultured in RPMI 1640 medium supplemented with $10 \%$ heat-inactivated FBS, 1\% streptomycin and penicillin, $10 \mathrm{ng} / \mathrm{ml}$ GM-CSF and IL4) in 6-well plates (Corning, Cambridge, MA) and incubated at $37^{\circ} \mathrm{C}$. After 3 days, non-adherent granulocytes were removed when the spent medium was replaced with fresh. On day 6, non-adherent and loosely adherent DC aggregates were harvested and subcultured overnight. The non-adherent cells, $>90 \%$, were used as immature DCs for studies on day 7, see below.

\section{Exposure of DCs to the recombinant $B$. subtilis-cap}

On day 7, immature DCs were seeded into 24-well plates $\left(5 \times 10^{5}\right.$ cells/well $)$ and treated with $10 \mathrm{ng} / \mathrm{ml}$ of LPS (positive control) or recombinant B. subtilis $\left(10^{7} \mathrm{CFU} /\right.$ well) for $24 \mathrm{~h}$ at $37^{\circ} \mathrm{C}$. Cells were then washed twice with cold PBS and stained with fluorescent mAbs specific for mouse CD40, CD80, and MHC II for $0.5 \mathrm{~h}$ at $4{ }^{\circ} \mathrm{C}$ as per manufacturer's guidelines. Cells were washed three times with PBS then subjected to flow cytometry.

\section{Allogenic mixed lymphocyte reaction}

The functional activity of DCs was reflected in the primary allogeneic mixed lymphocyte reaction assay. $\mathrm{T}$ cells were purified from the mesenteric lymph nodes of allogeneic BALB/c mice by using a $\mathrm{T}$ cell isolation kit and then labeled with CFSE according to manufacturer's instructions. Responder T cells $\left(5 \times 10^{5} /\right.$ well $)$ were cocultured with BM-DCs (DCs/T cell ratios of 1:1) in 24wells plates for 5 days in $5 \% \mathrm{CO}_{2}$ incubator at $37^{\circ} \mathrm{C}$ and then subjected to flow cytometry analysis.

\section{Immunization schedule and sample collection}

To evaluate the immunogenicity of recombinant $B$. subtilis-Cap strain as an oral vaccine, 24 neonatal Yorkshire piglets were randomly allocated to four immunization groups: Ctrl, B. subtilis, inactivated PCV2, and B. subtilis-Cap; all immunizations were done orally. Each piglet in the B. subtilis-treated groups was administered B. subtilis preparation $\left(10^{10} \mathrm{CFU} / \mathrm{ml}, 10^{10} \mathrm{CFU} / \mathrm{kg}\right.$ B. subtilis) $1 \mathrm{ml}$ on day $0,2 \mathrm{ml}$ on day 7 and $8 \mathrm{ml}$ on day 35, while the piglets in the Ctrl group were given the same volumes of PBS, the piglets in the inactivated PCV2 group were given $100 \mu \mathrm{g} /$ dose of inactivated PCV2. Serum, oropharyngeal swabs, nasal swabs, and feces were collected at weekly intervals after the second immunization, and piglets were not allowed to ingest anything for the $2 \mathrm{~h}$ previous to sample collection. Serum was collected from the jugular vein of the piglets. Oropharyngeal samples were taken by allowing the piglets to bite a swab four times. Nasal swabs were introduced $3 \mathrm{~cm}$ into the nose. $0.3 \mathrm{~g}$ of feces were collected using a cotton swab introduced $4 \mathrm{~cm}$ into the rectum. Samples were transported on dry ice to the research lab, where they were placed in tubes containing $0.5 \mathrm{ml}$ cold PBS, vortexed at least $30 \mathrm{~s}$ and clarified by centrifugation at $2500 \times \mathrm{g}$ for $10 \mathrm{~min}$ at $4{ }^{\circ} \mathrm{C}$. The clarified washes were stored at $70{ }^{\circ} \mathrm{C}$ until use for PCV2-specific IgA and IgG detection by ELISA, see below. All piglets were sacrificed on day 39 , ileums were removed and transported on dry ice to the research lab. $100 \mathrm{mg}$ of frozen ileal tissue from each piglet was homogenized in $1 \mathrm{ml}$ of RIPA buffer (containing phosphatase and protease inhibitors) for western blot or $1 \mathrm{ml}$ of PBS for cytokine detection with a Brinkman homogenizer at low speed for 2-3 min. Tissue RIPA buffer homogenates were then centrifuged at $12,000 \times \mathrm{g}$ for $10 \mathrm{~min}$ at $4{ }^{\circ} \mathrm{C}$ and tissue PBS homogenates were then centrifuged at $2500 \times \mathrm{g}$ for $10 \mathrm{~min}$ at $4{ }^{\circ} \mathrm{C}$. Supernatants were collected and stored at $-70{ }^{\circ} \mathrm{C}$ until further use. The protein concentration of the supernatants was determined by BCA protein assay according to the manufacturer's directions.

\section{Serum neutralization assays}

PCV2 neutralizing activity in sera from swine was detected on day 21 and day 28 by a fluorescent focus neutralizing assay as previously described [8]. Briefly, the serum samples were heat inactivated at $56^{\circ} \mathrm{C}$ for $30 \mathrm{~min}$ and fifty microlitres of the serum samples were serially diluted in DMEM medium ( $\mathrm{pH}$ 7.0) in two-fold with a starting dilution of $1: 2$ to $1: 4096$. Then $200 \mathrm{TCID}_{50}$ of PCV2 $\left(4 \times 10^{3} \mathrm{TCID}_{50} \mathrm{ml}^{-1}, 50 \mu \mathrm{l}\right)$ were mixed with equal volume of serum. After incubation for $1 \mathrm{~h}$ at $37^{\circ} \mathrm{C}$, the mixtures were added to a 96-well plate containing 40-50\% confluent PK-15 cells and incubated at $37^{\circ} \mathrm{C}$ for $1 \mathrm{~h}$. Then, the inoculum were removed, cells were washed with DMEM three times and complete medium were added for incubation. After $72 \mathrm{~h}$, the cells were washed twice with PBS and fixed with cold acetone/ methanol $(1 / 1 \mathrm{v} / \mathrm{v})$ at $-20^{\circ} \mathrm{C}$ for $20 \mathrm{~min}$, and blocked with $3 \% \mathrm{BSA}$ in PBS for $1 \mathrm{~h}$ at room temperature, and then air-dried. The cells were incubated with anti-Cap monoclonal antibodies diluted at 1:100 with PBS containing $1 \%$ BSA for $1 \mathrm{~h}$ at $37^{\circ} \mathrm{C}$, and then followed by staining with Dylight 488 goat anti-mouse IgG $(\mathrm{H}+\mathrm{L})$ (1:200) as second antibody at $37^{\circ} \mathrm{C}$ for $1 \mathrm{~h}$ in the dark. All cells were washed 3 times with PBS and read under a fluorescent microscope. Cells with Dylight 488 staining were recorded as infected. Once a plate was validated, neutralizing antibody (NA) titers were determined as the reciprocal of the highest serum dilution at $50 \%$ or 
greater fluorescent focus reduction in the infected cell cultures under a fluorescent microscope.

\section{Levels of PCV2-specific $\lg A$, IgG, and cytokines in piglet samples}

Levels PCV2-specific IgA from saliva, the nasal cavity, and feces and IgG in serum were measured by ELISA according the manufacturer's recommended protocol. The signal to noise $(\mathrm{S} / \mathrm{N})$ value was calculated as follows:

$$
\mathrm{S} / \mathrm{N}=\frac{(\mathrm{OD} 450 \text { of sample well-OD450 of bank control well })}{(\mathrm{OD} 450 \text { of negative control well-OD450 of bank control well })}
$$

Cytokine levels in the ileum suspensions were measured using commercial ELISA kits according to the manufacturer's instructions. Absorbance was measured at $450 \mathrm{~nm}$ with an automated ELISA reader.

\section{Histological examination of intestinal intraepithelial lymphocytes (IELs)}

Ileal tissues from slaughtered piglets were fixed with Bonn's liquid, embedded in paraffin, and serially sectioned ( $5 \mu \mathrm{m}$ per section). Five non-successive sections from the same location of ileum tissue were selected and stained with hematoxylin-eosin (H/E). Tissue sections were visualized with a $40 \times$ objective on an Olympus BH2 microscope. Measurement of the IELs was done as described [47]. Briefly, ten well-oriented villi and crypts, the longest in each field, were selected and the number of IELs counted; the means of these counts were calculated to yield a single value per pig. All the data were used for statistical analysis and expressed as the average number of cells.

\section{Immunohistochemical detection of IgA secreting cells, $\mathrm{CD}^{+}, \mathrm{CD}^{+}$, and $\mathrm{CD}^{+} \mathrm{T}^{\text {lymphocytes }}$}

Paraffin sections were dewaxed in xylene and rehydrated in decreasing concentrations of ethanol. For immunohistochemical staining, antigen retrieval was performed for 30 min with citrate buffer at $\mathrm{pH} 6.0$ in a Decloaking Chamber at $95{ }^{\circ} \mathrm{C}$. Slides were blocked with $5 \%$ normal goat serum then incubated with primary antibody (1: 100) overnight at $4{ }^{\circ} \mathrm{C}$ in a humidified chamber. Sections incubated in buffer only served as the negative control. The SABC-POD (rabbit or mouse IgG) kit and peroxidase substrate kit were used for amplification and visualization of signal, respectively. Following each incubation step, sections were washed 4 times, each wash was in fresh PBS-Tween. The sections were visualized with an Olympus $\mathrm{BH}-2$ microscope, and ten fields were selected from each section $(40 \times)$. The regions that contained IgA secreting cells, $\mathrm{CD}^{+}, \mathrm{CD}^{+}$, and $\mathrm{CD} 8^{+} \mathrm{T}$ lymphocytes were counted using the Image-Pro Plus analysis program (Cambridge, UK), data are expressed as the average IOD of cells.

\section{Extraction of total protein and western blotting assay}

TLR2 and TLR9 protein levels in ileal tissue homogenates were determined by western blot. Equal amounts of protein were mixed with $5 \times$ SDS-PAGE sample loading buffer, incubated $10 \mathrm{~min}$ in a boiling water bath then separated on a $10 \%$ SDS-PAGE gel. Proteins were transferred onto a $0.22 \mu \mathrm{m}$-pore polyvinylidene difluoride membrane (PVDF; Merck Millipore) at $110 \mathrm{~V}$ for $1 \mathrm{~h}$ using a wet-transfer apparatus in an ice bath. The membranes were blocked for $2 \mathrm{~h}$ with 5\% skim milk in PBST (PBS-0.1\% Tween-20) and then incubated with primary antibodies (1:1000) at $4{ }^{\circ} \mathrm{C}$ overnight. After washing with PBST $/ 0.1 \%$ BSA, the membranes were incubated with horseradish peroxidase (HRP)-conjugated secondary antibodies (1:5000) for $1 \mathrm{~h}$ at room temperature. After additional washing, bound conjugates were detected by enhanced chemiluminescence. Proteins were visualized using an electro-chemiluminescence visualization system (Tanon, Shanghai, China) and then the net intensities of the individual bands were measured using Quantity One (Quantity One 1-D Analysis Software 170-9600, BioRad). The density of the bands was measured and GAPDH was used as the loading control, and TLR2 and TLR9 protein expression were normalized to GAPDH.

\section{Statistical analysis}

Data are presented as means \pm standard deviation (SD) from three independent experiments. Statistical analysis was performed using the Statistical Program for Social Sciences (SPSS) 16.0. Significant differences between control and experimental groups were analyzed by Student's $t$-test and one-way ANOVA. Differences were considered statistically significant at $* 0.01<p<0.05$, ** $p<0.01$.

\section{Results}

Construction of pHT43-cap shuttle plasmid and expression of cap protein in recombinant $B$. subtilis

The PCV2 Cap sequence was inserted downstream from the Pgrac site in pHT43, resulting in pHT43-Cap (Fig. 1a). pHT43-Cap and empty pHT43 were transformed into $B$. subtilis by electroporation. A western blot of extracts of transformed B. subtilis-Cap and B. subtilis-pHT43 (named B. subtilis) probed with mouse anti-Cap mAbs, revealed a $30 \mathrm{kDa}$ band in B. subtilis-Cap and not in B. subtilis (Fig. 1d). $30 \mathrm{kDa}$ corresponds to the molecular mass of the PCV2 Cap protein. These results demonstrate that the Cap protein was expressed in B. subtilis with effective antigenicity. 


\section{B. subtilis-cap stimulation of BM-DC maturation in vitro} DCs play an important role in capturing antigens and activating the immune response. When immature DCs contact an antigen they activate into mature cells and up-regulate the expression of co-stimulatory and antigen presentation associated factors [48]; this phenotypic maturation of DCs is essential for T cells activation. To determine whether $B$. subtilis-Cap could stimulate the maturation of bone marrow dendritic cells, we used specific antibodies to detect the surface expression of CD40, CD80, and MHCII in mouse BM-DCs by FACS. As shown in Fig. 2a-f, compared to immature BM-DCs, the expression of CD40, CD80, and MHC II were significantly increased $(P<0.01)$ after being stimulated by $B$. subtilis, B. subtilis-Cap or LPS. B. subtilis-Cap elicited a greater stimulatory response than B. subtilis or Ctrl.
The immune stimulatory effects of DCs on T cells and $\mathrm{T}$ lymphocyte proliferation are crucial to the adaptive immune response. After stimulation with B. subtilis, B. subtilis-Cap, and LPS in vitro, an allogenic mixed lymphocyte reaction (MLR) was performed to determine the ability of activated BM-DCs to induce allogenic $\mathrm{T}$ cell proliferation. As shown in Fig. $2 \mathrm{~g}$ and $\mathrm{h}, \mathrm{BM}-\mathrm{DCs}$ stimulated by B. subtilis and B. subtilis-Cap increase allogeneic $\mathrm{T}$ cells proliferation compared with those in the untreated control group $(P<0.01)$. Previous studies have reported that the ratio of $\mathrm{CD}^{+} \mathrm{T}$ cells to $\mathrm{CD} 8^{+} \mathrm{T}$ cells plays a central role in the induction of efficient immune responses against diseases such as human immunodeficiency virus and some cancers [49-51]. The ratio of $\mathrm{CD}^{+}$to $\mathrm{CD}^{+} \mathrm{T}$ cells in the B. subtilis-Cap group was significantly higher than in other groups

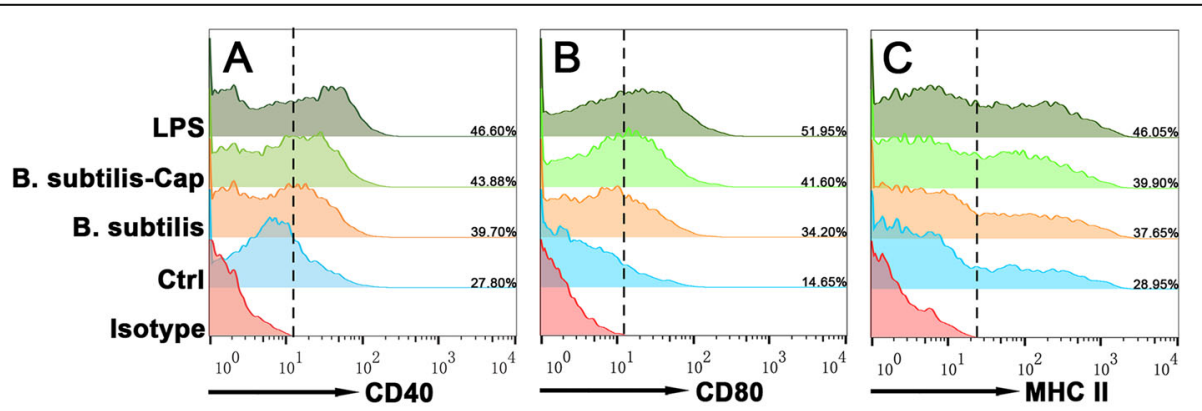

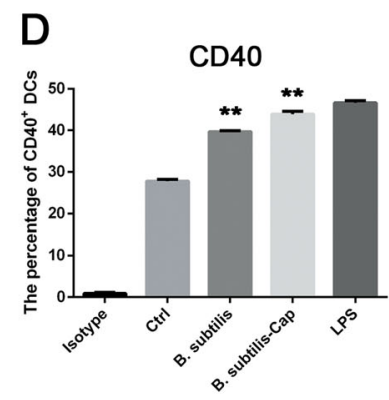

G

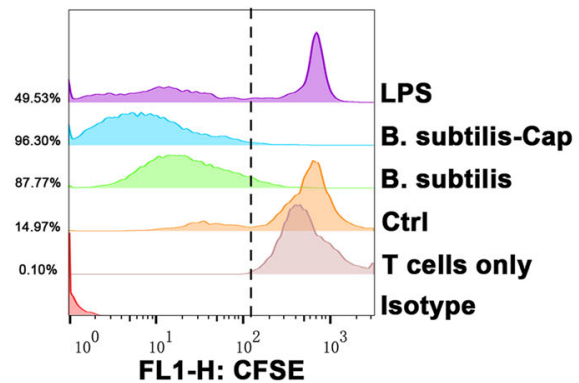

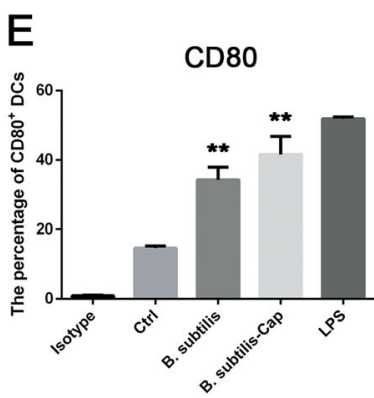

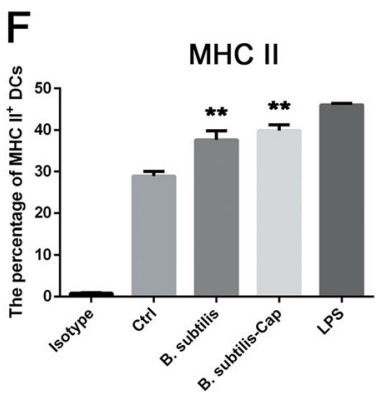

$\mathrm{H}$

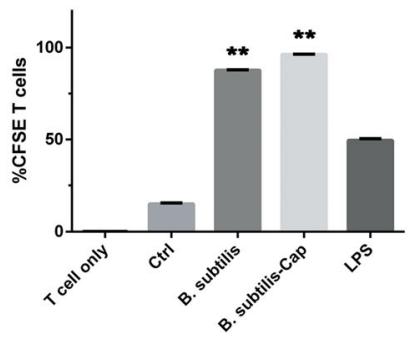

Fig. 2 B. subtilis-Cap stimulates phenotypic alteration of BM-DCs and promotes T cells proliferation in vitro. a-f B. subtilis, B. subtilis-Cap, and LPS, were incubated with mouse BM-DCs for $24 \mathrm{~h}$. Expression of CD40, CD80, and MHCIl were analyzed by flow cytometry. Untreated BM-DCs served as a negative control. $\mathbf{g}$ and $\mathbf{h}$ Mixed lymphocyte reaction (MLR) experiments. B. subtilis, B. subtilis-Cap, LPS, or PBS treated BM-DCs were cocultured with carboxyfluorescein succinimidyl ester (CFSE)-labeled allogeneic T lymphocytes (DC:T cell ratio, 1:1) for another 5 days. Untreated BMDCs co-cultured with T lymphocytes served as a negative control. T lymphocytes proliferation was evaluated by flow cytometry. Data are presented as means \pm SD from three independent experiments. $\left({ }^{*} 0.01<p<0.05,{ }^{* *} p<0.01\right.$ ) 
(Additional file 1: Figure S1), demonstrating that the recombinant B. subtilis-Cap effects an efficient immune response against PCV2.

\section{Immune response in piglets orally inoculated with $B$. subtilis-cap}

We evaluated the mucosal and systemic immune responses in Balb/c mice orally inoculated with B. subtilis, B. subtilis-Cap, and inactivated PCV2. PCV2-specific IgA levels in ileum fluids from the B. subtilis-Cap, and inactivated PCV2 dosed mice, rose in concert over the course of 21 days, then declined. In mice inoculated with B. subtilis-Cap, the rise was steeper and the decline was shallower than in mice dosed with inactivated PCV2. On day 35 post inoculation the IgA levels in the intestines of B. subtilis-Cap dosed mice were still elevated, while in mice dosed with inactivated PCV2, the IgA levels had declined to background (Additional file 2: Figure S2a). PCV2-specific IgG levels in serum from the B. subtilisCap, and inactivated PCV2 dosed mice rose in concert over the course of 14 days, between day 14 and 28, the serum IgG levels in the B. subtilis-Cap dosed mice continued to rise, then slightly decline between day 28 and 35 , while in the mice dosed with inactivated PCV2, serum IgG levels declined to background after day 14 (Additional file 2: Figure S2b). These results demonstrated that recombinant B. subtilis-Cap could effectively stimulate an immune response against PCV2.

We then repeated this experiment in piglets. As shown in Fig. 3, the levels of PCV2-specific IgA antibody in saliva, nasal cavities, and feces, of piglets inoculated with $B$.
subtilis-Cap rose steadily over the time course of the experiment and were for the most part significantly increased over inactivated PCV2 throughout the experiment. In all but the nasal cavity samples, the levels of IgA in the piglets inoculated with B. subtilis-Cap remained elevated throughout the 35-day experiment, while in those inoculated with inactivated PCV2, IgA levels rose initially then dropped to background. PCV2-specific IgG levels in sera from B. subtilis-Cap inoculated piglets were significantly higher than from inactivated PCV2 inoculated piglets throughout the experiment. Furthermore, serum samples on day 21 and day 28 were further evaluated for the ability to neutralize PCV2 in vitro by serum neutralization assays. As shown in Fig. 3f, neutralizing antibody (NA) titers against PCV2 in the recombinant $B$. subtilis-Cap group were significantly higher than sera from other groups $(P<0.01)$. Swine immunized with recombinant $B$. subtilis-Cap developed mean NA titers of $1: 6.3$ on day 21 and 1: 14.3 on day 28. Sera from swine treated with PBS in Ctrl group was showed no neutralizing antibody activity, and sera from B. subtilis and Inactived PCV2 groups were showed a lower level of NA titers. These results demonstrate the effectiveness of B. subtilis as a viral vector for oral PCV2 vaccine delivery.

\section{Local cellular immune responses in ileums after oral immunization}

Because the levels of mucosal PCV2-specific IgA antibody increased significantly following inoculation with recombinant $B$. subtilis-Cap, we next looked at the IgAsecreting cells in the piglets' ileums by immunohistochemistry. We found that the average integrated optical density (IOD) of IgA-producing cells in ileums were

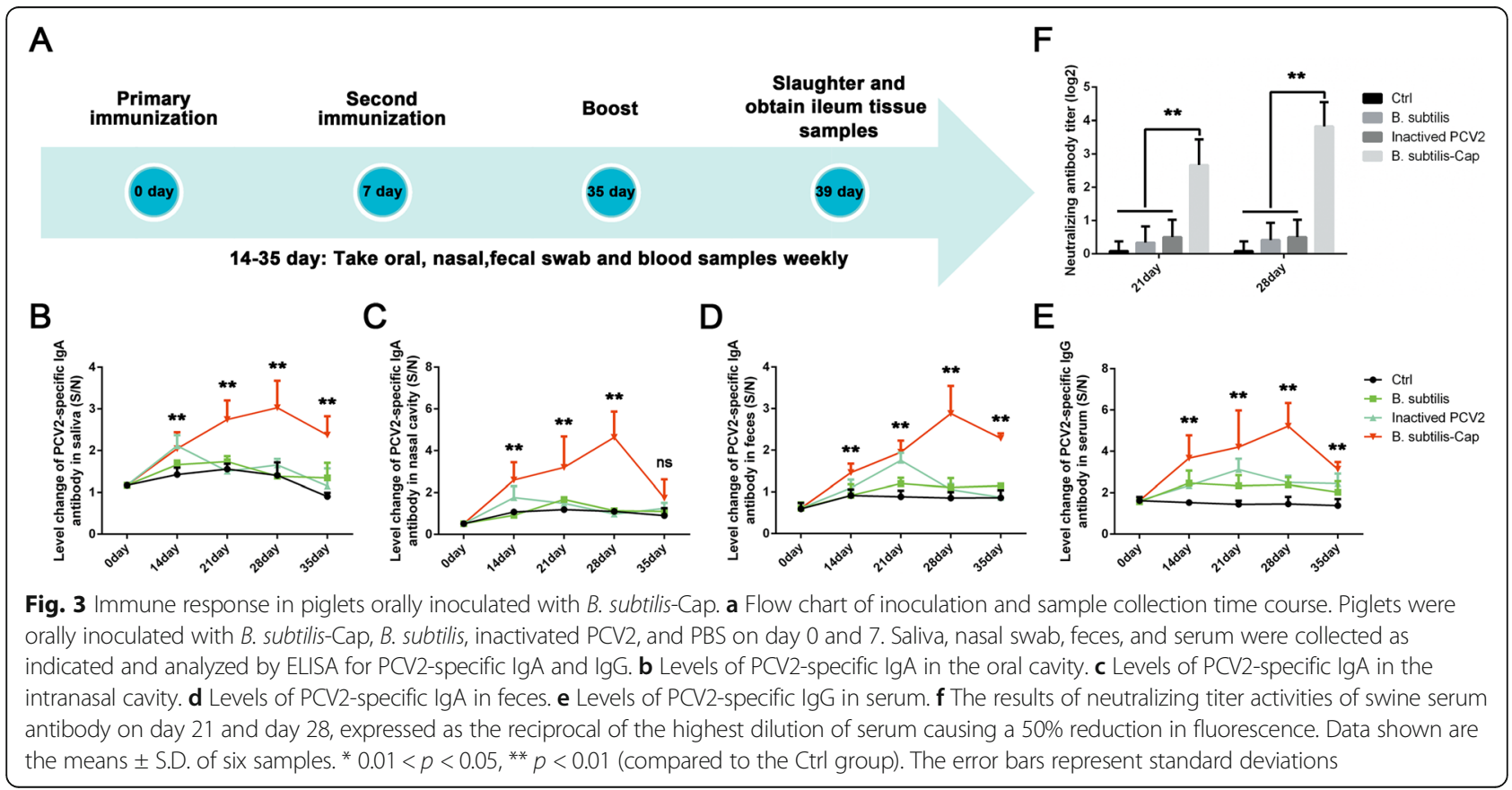


increased significantly $(P<0.01)$ after stimulation with recombinant $B$. subtilis-Cap (Fig. 4a). The number of intestinal intraepithelial lymphocytes (IELs) in the ileums of B. subtilis-Cap inoculated piglets were significantly higher $(P<0.01$, Fig. $4 \mathrm{~b})$ than in the control piglets. IELs, found in the epithelial layer of mucosal tissues, are involved in the recognition of and defense against pathogens. The average IOD of $\mathrm{CD}^{+}$and $\mathrm{CD} 4^{+} \mathrm{T}$ lymphocytes in the ileums of B. subtilis-Cap inoculated piglets were significantly higher than in the control piglets $(P<0.01$, Fig. $4 \mathrm{c}$ and $\mathrm{d})$. In contrast, $\mathrm{CD} 8^{+} \mathrm{T}$ lymphocytes did not appear to be stimulated in any of the experimental piglets $(P>0.05$, Fig. 4e). These results demonstrated that oral immunization with recombinant

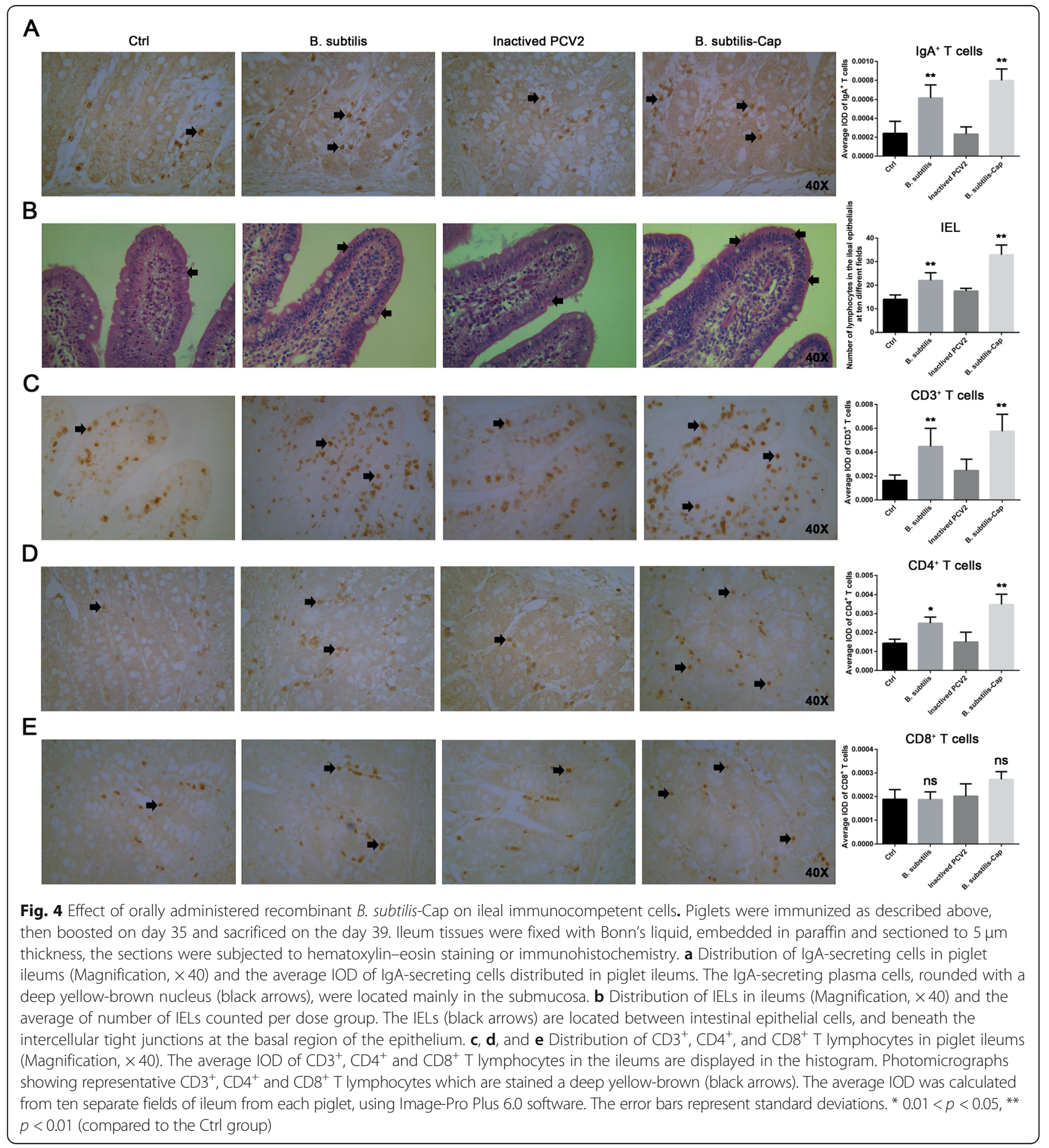


B. subtilis-Cap resulted in increased lymphocytes and a robust immune response in the ileums of piglets.

\section{Levels of TLRs and cytokines}

To further investigate the mucosal-cell immune response after oral inoculation, we tested for expression of TLR2, TLR9, IgA and associated cytokines in the ileum homogenates prepared after piglets were sacrificed. In piglets dosed with B. subtilis-Cap, levels of TLR2 (Fig. 5a) and TLR9 (Fig. 5b) protein, as well as IgA (Fig. 5c) were increased significantly over controls $(P<0.01)$. Activation of the immune response is usually associated with the secretion of cytokines; compared with piglets immunized with PBS or inactivated PCV2, the ileum homogenates from piglets immunized with $B$. subtilis and $B$. subtilis-Cap had significantly $(P<0.01)$ increased levels of IL-1 $\beta$ (Fig. 5d), IL-6 (Fig. 5e), IFN- $\gamma$ (Fig. 5h), and $\beta$ defensin 2 (Fig. 5i), which is crucial for the innate immune system of gut protection owing to its antimicrobial, antiviral, and immunomodulatory activities $[52,53]$. Levels of IL-10 (Fig. 5f) and TNF- $\alpha$ (Fig. 5g) were unchanged $(P>0.05)$.

\section{Discussion}

Porcine circovirus type 2 (PCV2), the etiologic agent of post-weaning multi-systemic wasting syndrome (PMWS) has become a considerable economic burden to swine industries worldwide. PCV2 infects animals through the mucosal tissues of their respiratory and intestinal tracts [21-24]. Current vaccines administered parenterally induce neutralizing IgG antibodies in the serum, which may not play a substantial role in protecting against PCV2 infection since protection is primarily dependent on secretory IgA antibodies. The control of PCV2 infection requires a mucosal vaccine with a safe and effective agent; to address this need we constructed a recombinant B. subtilis that expresses the capsid protein of PCV2, B. subtilis-Cap. The capsid protein is the most immunogenic of PCV2 [6-8], and B. subtilis is widely used as a live vaccine vehicle for heterologous antigen delivery. It effectively elicits mucosal and systemic immune responses [42, 54-56], and itself possesses adjuvant-like properties enhancing the level of local and systemic immune responses [37, 57, 58]. Wang et al. reported that in mice, oral vaccination with Lactococcus lactis

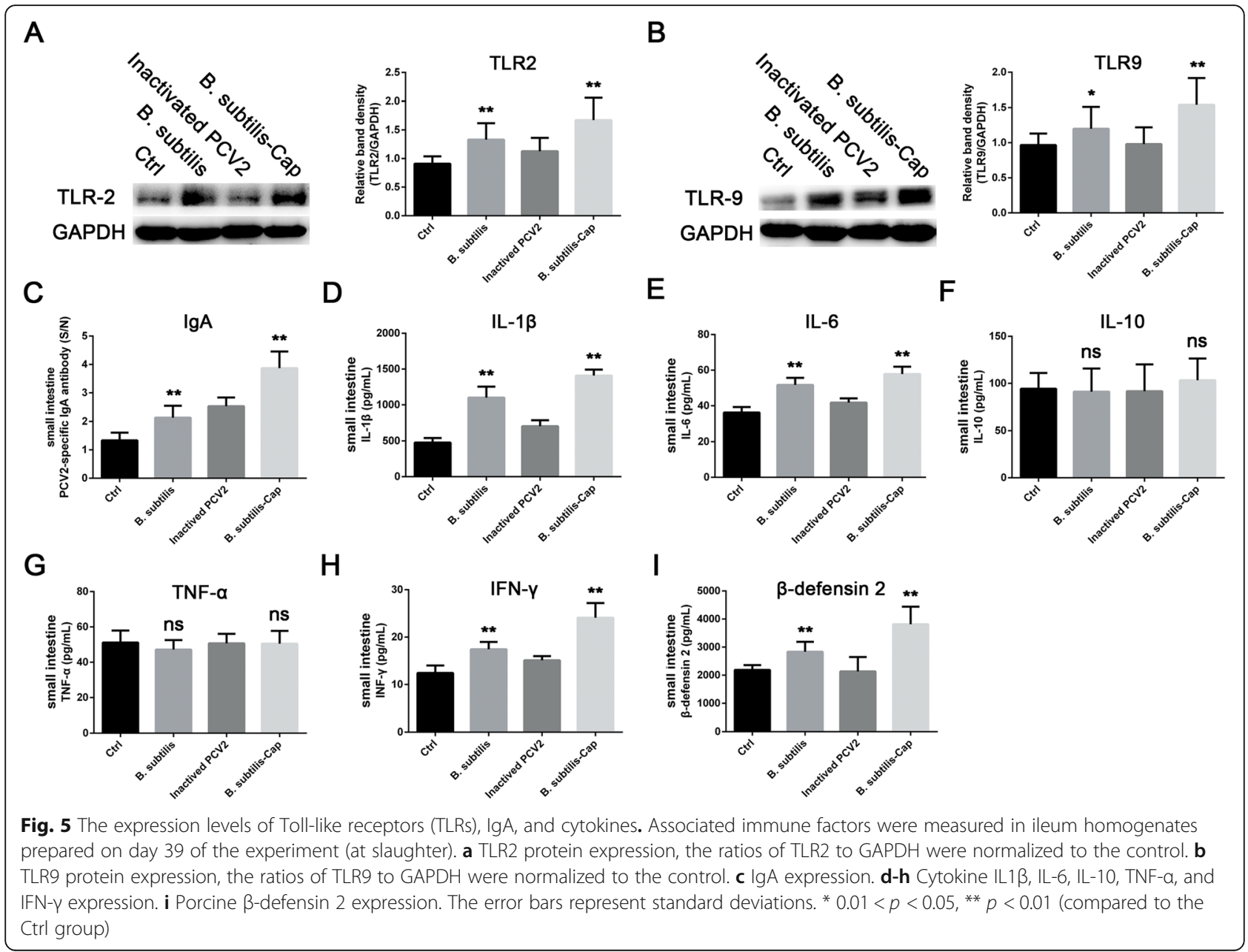


expressing PCV2 capsid protein resulted in enhanced expression of PCV2-specific IgA, there was however no effect on IgG expression [59]. In our study, piglets orally vaccinated with $B$. subtilis-Cap had induced robust humoral immune response by increasing levels of PCV2specific $\operatorname{IgA}$ and $\operatorname{IgG}$ compared with piglets orally vaccinated with inactivated PCV2.

Dendritic cells are antigen-presenting cells widely distributed in the intestinal submucosa, they play a crucial role in linking innate and adaptive immunities [60, 61]. The development of DCs include immature stage (iDCs) and mature stage (mDCs). IDCs are specialized in antigen capture and processing, and are characterized by low expression of MHCII and co-stimulatory molecules on their surface. Upon contacting an antigen they activate into mature DCs and up-regulate antigen presentation associated factors and ultimately stimulate specific $\mathrm{T}$ cell immune responses [48, 62, 63]. Previous studies have demonstrated that $B$. subtilis enhances the expression of chemokine CCL20 in intestinal epithelial cells, recruits immature DCs into the intestinal epithelium, stimulates mature DC migration to mesenteric lymph nodes $[64,65]$. It has also been reported that PCV2induced immunosuppressive effects are owing to the specific silencing of plasmacytoid DCs, resulting in their failure to deliver pathogen-associated 'danger' signals [66]. Here we found that B. subtilis-Cap enhanced the MHC II and co-stimulatory molecules of BM-DCs. In addition, DCs sensitized by B. subtilis-Cap stimulated the proliferation of $\mathrm{T}$ lymphocytes. These results demonstrate that exposure to B. subtilis-Cap caused the maturation of DCs and the induction of the attendant immune response.

Secretory $\operatorname{IgA}(\operatorname{sg} \mathrm{A})$ is a major contributor to host defense at mucosal surfaces and plays a critical role in mucosal immunity. sIgA maintains mucosal homeostasis by regulating the composition of intestinal microflora and limiting the acute local inflammation induced by the invasion and colonization of pathogens [67, 68]. Serum IgG is the most abundant immunoglobulin in the blood, is vital for systemic immunity. Our experiments showed that oral immunization with B. subtilis-Cap resulted in elevated PCV2-specific IgA antibodies in saliva, nasal cavity, ileum and feces, as well as elevated PCV2-specific IgG in serum, demonstrating that oral immunization can elicit both mucosal and systemic immune responses effectively.

B. subtilis itself not only broadens the antibody response, but also increases $\mathrm{T}$ cell responses [36]. Intestinal intraepithelial lymphocytes are sentinel $\mathrm{T}$ lymphocytes in the intestinal tract, functioning in immune surveillance and defense against pathogens [69-71]. $\mathrm{CD}^{+} \mathrm{T}$ lymphocytes are mainly distributed in the lamina propria of the ileum, while $\mathrm{CD}_{4}^{+} \mathrm{T}$ cells (helper $\mathrm{T}$ cells) enhance the cytotoxicity mediated by $\mathrm{CD} 8^{+} \mathrm{T}$ cells. The ratio of $\mathrm{CD} 4^{+}$ $\mathrm{T}$ cells to $\mathrm{CD}^{+} \mathrm{T}$ cells are an important factor in determining immunity states and levels [72, 73], and plays a central role in the induction of efficient immune responses against different diseases such as human immunodeficiency virus (HIV) and cancer [11-14]. Consist to previous study [74], the ratio of $\mathrm{CD} 4^{+} \mathrm{T}$ cells to $\mathrm{CD} 8^{+} \mathrm{T}$ cells was also increased significantly in mice immunized with B. subtilis-Cap. We found that in the intestinal tract of piglets orally administration of B. subtilis-Cap, the number of IgA producing plasma cells, IELs, $\mathrm{CD}^{+}$, and $\mathrm{CD} 4^{+} \mathrm{T}$ lymphocytes were significantly increased. Toll-like receptors (TLR) activation also plays an important role in regulating mucosal immune responses in the intestine. TLRs are major class of pattern recognition receptors that recognize specific molecules generally shared by pathogens including virus, bacteria, and fungi [75-79]. B. subtilis is recognized by TLR2 and TLR9 which triggers both innate and adaptive immune responses, eliciting the production of immunomodulatory cytokines and chemokines, and upregulating the co-stimulatory molecules of DCs $[37,40,58,80,81]$. We found that in the ileal cells of piglets orally administered B. subtilis-Cap, expression of TLR2 and TLR9 was significantly elevated, as was secretion of IL-1 $\beta$, IL- 6 , and IFN- $\gamma$. Among the experimental piglets, there were however no significant differences in the expression of IL-10 or TNF- $\alpha$, which may due to inhibition by IL-6. B. subtilis-Cap immunization also resulted in increased $\beta$-defensin-2 levels, which is beneficial for the growth performance and improve the intestinal health.

\section{Conclusions}

Recombinant B. subtilis-Cap stimulated the maturation of BM-DCs in vitro. In piglets orally immunized with $B$. subtilis-Cap, humoral and cellular immunity was enhanced as demonstrated by the upregulation of PCV2specific IgA and IgG antibodies. These results indicate that recombinant $B$. subtilis-Cap is a promising candidate in the effort to develop new PCV2 vaccines.

\section{Supplementary information}

Supplementary information accompanies this paper at https://doi.org/10. 1186/s12964-020-0514-4

Additional file 1: Figure S1. Effect on $\mathrm{CD}^{+}{ }^{+}$to $\mathrm{CD} 8^{+} \mathrm{T}$ cells. Mesenteric lymph node cells isolated from healthy mice 35 days after inoculation were cultured in lymphocyte culture medium at $2 \times 10^{5}$ cells per well in 24-well culture plates, and stimulated by recombinant B. subtilis-Cap for $72 \mathrm{~h}$. Non-stimulated cells were used as negative controls. $\mathbf{a}$ and $\mathbf{b}$ The percentage of $\mathrm{CD}^{+} \mathrm{T}$ cells $(\mathrm{Q} 2)$. $\mathbf{c}$ The gates were based on $\mathrm{CD}^{+} \mathrm{T}$ cell results (Q2), then further gated for $\mathrm{CD}^{+}$and $C D 8^{+} \mathrm{T}$ cells. $\mathbf{d}$ The ratio of $\mathrm{CD}^{+}$to $\mathrm{CD}^{+} \mathrm{T}$ cells for each group. The error bars represent standard deviations. ${ }^{*} 0.01<p<0.05,{ }^{* *} p<0.01$ (compared to the Ctrl group).

Additional file 2: Figure S2. Mice were inoculated orally with $B$. subtilis, B. subtilis-Cap, inactivated PCV2, and PBS on days 0 and 7. Intestinal fluids 
and sera were collected on days 14,21,28, and 35. Endpoint titers (or absorbance at $450 \mathrm{~nm}$ ) of PCV2-specific intestinal IgA and serum IgG antibodies were investigated by ELISA. a Levels of PCV2-specific IgA in intestinal fluids. $\mathbf{b}$ Levels of PCV2-specific lgG antibody in serum. The error bars represent standard deviations. ${ }^{*} 0.01<p<0.05,{ }^{* *} p<0.01$ (compared to the Ctrl group).

\section{Abbreviations}

B. subtilis: Bacillus subtilis; BM-DCs: Bone marrow-derived dendritic cells; Cap: Capsid protein; PCV2: Porcine circovirus type 2

\section{Acknowledgments}

We thank Dr. Xuewen Gao for Bacillus subtilis WB800N and pHT43, and Dr. Ping Jiang for the PCV2 virus and mouse anti-Cap mAbs, and Jialu Wang for technical assistance.

\section{Authors' contributions}

All authors have contributed substantially to this work. The study was designed by SZ and YC. SZ and YC did all the experiments. CM and EZ participated in conducting the experiments. SZ, CM, and QY discussed and interpreted findings. SZ designed figures and wrote the manuscript with YC. QY supervised the experiments and directed the work. All of the authors have seen and approved the final version of the manuscript.

\section{Funding}

This work was supported by grants from the National Natural Science Foundation of China (31930109 and 31772777) and a project funded by the Priority Academic Program Development of Jiangsu Higher Education Institutions (PAPD).

\section{Availability of data and materials}

All data generated or analyzed during this study are included either in this article or in the supplementary Materials and Methods, Tables, Figures and Figure Legends files.

\section{Ethics approval and consent to participate}

All animal studies were approved by the Institutional Animal Care and Use Committee of Nanjing Agricultural University, and followed the National Institutes of Health guidelines for the performance of animal experiments.

\section{Consent for publication}

Not applicable.

\section{Competing interests}

The authors declare they have no competing interests.

Received: 30 June 2019 Accepted: 17 January 2020

Published online: 11 February 2020

\section{References}

1. Lefkowitz EJ, Dempsey DM, Hendrickson RC, Orton RJ, Siddell SG, Smith DB. Virus taxonomy: the database of the international committee on taxonomy of viruses (ICTV). Nucleic Acids Res. 2018;46:D708-17.

2. Tischer I, Gelderblom H, Vettermann AW, Koch MA. A very small porcine virus with circular single-stranded DNA. Nature. 1982;295:64

3. Nawagitgul P, Morozov I, Bolin SR, Harms PA, Sorden SD, Paul PS. Open reading frame 2 of porcine circovirus type 2 encodes a major capsid protein. Jgenvirol. 2000;81:2281-7.

4. Allan GM, Ellis JA. Porcine Circoviruses: a review. J Vet Diagn Investig. 2000;12:3-14

5. Hamel AL, Lin LL, Nayar GPS. Nucleotide sequence of porcine Circovirus associated with Postweaning multisystemic wasting syndrome in pigs. J Virol. 1998:72:5262.

6. Nawagitgul P, Harms PA, Morozov I, Thacker BJ, Sorden SD, Lekcharoensuk C, Paul PS. Modified indirect porcine circovirus (PCV) type 2-based and recombinant capsid protein (ORF2)-based enzyme-linked immunosorbent assays for detection of antibodies to PCV. Clin Diagn Lab Immunol. 2002:9:33.

7. Blanchard P, Mahe D, Cariolet RA, Baudouard MA. Protection of swine against post-weaning multisystemic wasting syndrome (PMWS) by porcine circovirus type 2 (PCV2) proteins. Vaccine. 2003;21:4565-75.
8. Fort M, Olvera A, Sibila M, Segalés J, Mateu E. Detection of neutralizing antibodies in postweaning multisystemic wasting syndrome (PMWS)affected and non-PMWS-affected pigs. Vet Microbiol. 2007;125:244-55.

9. Albina E, Truong C, Hutet E, Blanchard P, Cariolet R, L Hospitalier R, Mahé D, Allée C, Morvan H, Amenna N. An experimental model for post-weaning multisystemic wasting syndrome (PMWS) in growing piglets. J Comp Pathol. 2001;125:292-303.

10. Zhao LF. Post-weaning multisystemic wasting syndrome in pigs. Prog Vet Med. 2004;146(3):84

11. Segalés J, Domingo M, Pozo MD, Sitjar M, Dee S, Noval R, Sacristan C, Heras $\mathrm{ADL}$, Ferro A, Latimer KS. First report of post-weaning multisystemic wasting syndrome in pigs in Spain. Vet Rec. 1997;141:600-1.

12. Chang SL, Chang CL, Chiang YM, Hsieh RH, Tzeng CR, Wu TK, Sytwu HK, Shyur LF, Yang WC. A review of porcine circovirus 2-associated syndromes and diseases. Vet J. 2005;169:326-36.

13. Opriessnig T, Meng XJ, Halbur PG. Porcine Circovirus type 2-associated disease: update on current terminology, clinical manifestations, pathogenesis, diagnosis, and intervention strategies. J Vet Diagn Investig. 2007;19:591.

14. Harding JC. The clinical expression and emergence of porcine circovirus 2. Vet Microbiol. 2004;98:131-5

15. Ladekjaer-Mikkelsen AS, Nielsen J, Storgaard T, Bã Tner A, Allan G, Mcneilly F. Transplacental infection with PCV-2 associated with reproductive failure in a gilt. Vet Rec. 2001;148:759-60.

16. O'Connor B, Gauvreau H, West K, Bogdan J, Ayroud M, Clark EG, Konoby C, Allan G, Ellis JA. Multiple porcine circovirus 2-associated abortions and reproductive failure in a multisite swine production unit. Canadian Vet $\mathrm{J} \mathrm{La}$ Revue Vétérinaire Canadienne. 2001;42:551-3.

17. Lee G, Han D, Song JY, Lee YS, Kang KS, Yoon S. Genomic expression profiling in lymph nodes with lymphoid depletion from porcine circovirus 2-infected pigs. J Gen Virol. 2010;91:2585-91.

18. Shibahara T, Sato K, Ishikawa Y, Kadota K. Porcine circovirus induces B lymphocyte depletion in pigs with wasting disease syndrome. J Vet Med Sci. 2000;62:1125-31

19. Segalés J, Allan GM, Domingo M. Porcine circovirus diseases. Anim Health Res Rev. 2005;6:119-42.

20. Fenaux M, Halbur PG, Gill M, Toth TE, Meng XJ. Genetic characterization of type 2 porcine circovirus (PCV-2) from pigs with postweaning multisystemic wasting syndrome in different geographic regions of North America and development of a differential PCR-restriction fragment length polymorphism assay to detect and differentiate between infections with PCV-1 and PCV-2. J Clin Microbiol. 2000;38:2494-503.

21. Shibata I, Okuda Y, Yazawa S, Ono M, Sasaki T, Itagaki M, Nakajima N, Okabe $Y$, Hidejima I. PCR detection of porcine circovirus type 2 DNA in whole blood, serum, oropharyngeal swab, nasal swab, and feces from experimentally infected pigs and field cases. J Vet Med Sci. 2003;65:405-8.

22. Baró J, Segalés J, Martínez J. Porcine circovirus type 2 (PCV2) enteric disease: an independent condition or part of the systemic disease? Vet Microbiol. 2015;176:83-7

23. Segales J. Porcine circovirus type 2 (PCV2) infections: clinical signs, pathology and laboratory diagnosis. Virus Res. 2012;164:10-9.

24. Yan M, Zhu L, Yang Q. Infection of porcine circovirus 2 (PCV2) in intestinal porcine epithelial cell line (IPEC-J2) and interaction between PCV2 and IPEC$J 2$ microfilaments. Virol J. 2014:11:193.

25. Beach NM, Meng XJ. Efficacy and future prospects of commercially available and experimental vaccines against porcine circovirus type 2 (PCV2). Virus Res. 2012;164:33-42

26. Chae C. Commercial porcine circovirus type 2 vaccines: efficacy and clinical application. Vet J. 2012;194:151-7.

27. Fachinger $V$, Bischoff $R$, Jedidia SB, Saalmuller $A$, Elbers $K$. The effect of vaccination against porcine circovirus type 2 in pigs suffering from porcine respiratory disease complex. Vaccine. 2008;26:1488-99.

28. Kixmöller M, Ritzmann M, Eddicks M, Saalmüller A, Elbers K, Fachinger V. Reduction of PMWS-associated clinical signs and co-infections by vaccination against PCV2. Vaccine. 2008:26:3443-51.

29. Li WL, Yang XJ, Feng Y, Guo YM, Yao JH. Effects of different immune stress on growth performance, nutrient digestibility and meat quality of broilers. Chinese J Animal Nutr. 2010;22(6):1551.

30. Bucarey SA, Noriega J, Reyes P, Tapia C, Saenz L, Zuniga A, Tobar JA. The optimized capsid gene of porcine circovirus type 2 expressed in yeast forms virus-like particles and elicits antibody responses in mice fed with recombinant yeast extracts. Vaccine. 2009;27:5781-90. 
31. Mohamadzadeh M, Duong T, Sandwick SJ, Hoover T, Klaenhammer TR. Dendritic cell targeting of Bacillus anthracis protective antigen expressed by Lactobacillus acidophilus protects mice from lethal challenge. Proc Natl Acad Sci U S A. 2009:106:4331-6.

32. Sim AC, Lin W, Tan GK, Sim MS, Chow VT, Alonso S. Induction of neutralizing antibodies against dengue virus type 2 upon mucosal administration of a recombinant Lactococcus lactis strain expressing envelope domain III antigen. Vaccine. 2008;26:1145-54.

33. Chen KL, Kho WL, You SH, Yeh RH, Tang SW, Hsieh CW. Effects of Bacillus subtilis var. natto and Saccharomyces cerevisiae mixed fermented feed on the enhanced growth performance of broilers. Poult Sci. 2009;88:309-15.

34. Xu QQ, Yan H, Liu XL, Lv L, Yin CH, Wang P. Growth performance and meat quality of broiler chickens supplemented with Rhodopseudomonas palustris in drinking water. Asian Australas J Anim Sci. 2012;25:682-9.

35. Lei $X$, Piao X, Ru Y, Zhang H, Péron A, Zhang H. Effect of Bacillus amyloliquefaciens-based direct-fed microbial on performance, nutrient utilization, intestinal morphology and Cecal microflora in broiler chickens. Asian Australas J Anim Sci. 2015;28:239-46.

36. Amuguni $\mathrm{H}$, Tzipori S. Bacillus subtilis: a temperature resistant and needle free delivery system of immunogens. Human Vaccines Immunother. 2012;8:979.

37. Barnes AG, Cerovic V, Hobson PS, Klavinskis LS, et al. Bacillus subtilis spores: A novel microparticle adjuvant which can instruct a balanced Th1 and Th2 immune response to specific antigen. Eur J Immunol. 2010;37:1538-47.

38. Davitt $\mathrm{CJH}$, Lavelle EC. Delivery strategies to enhance oral vaccination against enteric infections. Adv Drug Deliv Rev. 2015;91:52-69.

39. Driks A. Bacillus subtilis spore coat. Microbiolmolbiolrev. 1999;63:1-20.

40. Neutra MR, Kozlowski PA. Mucosal vaccines: the promise and the challenge. Nat Rev Immunol. 2006;6:148-58.

41. Holmgren J, Czerkinsky C. Mucosal immunity and vaccines. Nat Med. 2005:11:S45.

42. Mou C, Zhu L, Yang J, Xu W, Cheng X, Yang Q. Immune responses induced by recombinant Bacillus Subtilis expressing the Hemagglutinin protein of H5N1 in chickens. Sci Rep. 2016;6:38403.

43. Zhu X, Liu J, Bai J, Liu P, Zhang T, Jiang P, Wang X. Baculovirus expression of the $\mathrm{N}$-terminus of porcine heat shock protein Gp96 improves the immunogenicity of recombinant PCV2 capsid protein. J Virol Methods. 2016;230:36-44.

44. Narita J, Okano K, Kitao T, Ishida S, Sewaki T, Sung MH, Fukuda H, Kondo A. Display of alpha-amylase on the surface of Lactobacillus casei cells by use of the PgsA anchor protein, and production of lactic acid from starch. Appl Environ Microbiol. 2006;72:269-75.

45. Phan TT, Nguyen HD, Schumann W. Novel plasmid-based expression vectors for intra- and extracellular production of recombinant proteins in Bacillus subtilis. Protein Expr Purif. 2006:46:189-95.

46. Yin Y, Qin T, Wang X, Lin J, Yu Q, Yang Q. CpG DNA assists the whole inactivated H9N2 influenza virus in crossing the intestinal epithelial barriers via transepithelial uptake of dendritic cell dendrites. Mucosal Immunol. 2015;8:799-814.

47. Che C, Pang X, Hua X, Zhang B, Shen J, Zhu J, Wei H, Sun L, Chen P, Cui L, et al. Effects of human fecal flora on intestinal morphology and mucosal immunity in human flora-associated piglet. Scand J Immunol. 2009;69:223-33.

48. Banchereau J, Steinman RM. Dendritic cells and the control of immunity. Nature. 1998:392:245.

49. Frederiksen J, Buggert M, Noyan K, Nowak P, Sönnerborg A, Lund O, Karlsson AC. Multidimensional clusters of CD4+ T cell dysfunction are primarily associated with the CD4/CD8 ratio in chronic HIV infection. PLoS One. 2015;10:e0137635

50. Serrano-Villar S, Deeks SG. CD4/CD8 ratio: an emerging biomarker for HIV. Lancet Hiv. 2015;2:e76.

51. Wistuba-Hamprecht K, Di BS, Schilling B, Sucker A, Schadendorf D, Garbe C, Weide $B$, Pawelec G. Phenotypic characterization and prognostic impact of circulating $\gamma \delta$ and $a \beta$ T-cells in metastatic malignant melanoma. Int J Cancer. 2016;138:698.

52. Veldhuizen EJA, Rijnders M, Claassen EA, van Dijk A, Haagsman HP. Porcine $\beta$-defensin 2 displays broad antimicrobial activity against pathogenic intestinal bacteria. Mol Immunol. 2008;45:386-94

53. Han $F$, Zhang $H$, Xia $X$, Xiong $H$, Song D, Zong $X$, Wang Y. Porcine -Defensin 2 attenuates inflammation and mucosal lesions in dextran sodium sulfateinduced colitis; 2015

54. Mou C, Zhu L, Xing X, Lin J, Yang Q. Immune responses induced by recombinant Bacillus subtilis expressing the spike protein of transmissible gastroenteritis virus in pigs. Antivir Res. 2016;131:74-84.
55. Ferreira LC, Ferreira RC, Schumann W. Bacillus subtilis as a tool for vaccine development: from antigen factories to delivery vectors. An Acad Bras Cienc. 2005;77:113-24.

56. Mauriello EM, Duc LH, Isticato R, Cangiano G, Hong HA, De FM RE, Cutting SM. Display of heterologous antigens on the Bacillus subtilis spore coat using CotC as a fusion partner. Vaccine. 2004;22:1177-87.

57. Liang J, Fu J, Kang H, Lin J, Yu Q, Yang Q. Comparison of 3 kinds of toll-like receptor ligands for inactivated avian $\mathrm{H} 5 \mathrm{~N} 1$ influenza virus intranasal immunization in chicken. Poult Sci. 2013;92:2651-60.

58. de Souza RD, Batista MT, Luiz WB, Cavalcante RCM, Amorim JH, Bizerra RSP, Martins EG, de Souza Ferreira LC. Bacillus subtilis spores as vaccine adjuvants: further insights into the mechanisms of action. PLOS One. 2014;9:e87454.

59. Wang L, Zhao D, Sun B, Yu M, Wang Y, Ru Y, Jiang Y, Qiao X, Cui W, Zhou $\mathrm{H}$, et al: Oral vaccination with the porcine circovirus type 2 (PCV-2) capsid protein expressed by Lactococcus lactis induces a specific immune response against PCV-2 in mice. 2019.

60. Liu WC, Lin YL, Spearman M, Cheng PY, Butler M, Wu SC. Influenza Hemagglutinin glycoproteins with different $\mathrm{N}$-glycan patterns activate dendritic cells in vitro. J Virol. 2016;90:6085.

61. Rescigno M, Di Sabatino A. Dendritic cells in intestinal homeostasis and disease. J Clin Invest. 2009:119:2441-50.

62. Michiels A, Tuyaerts S, Bonehill A, Corthals J, Breckpot K, Heirman C, Meirvenne SV, Dullaers M, Allard S, Brasseur F. Electroporation of immature and mature dendritic cells: implications for dendritic cell-based vaccines. Gene Ther. 2005;12:772-82

63. Reis e SC. Dendritic cells in a mature age. Nat Rev Immunol. 2006;6:476-83.

64. Liu H, Xu W, Yu Q, Yang Q. 4,4'-Diaponeurosporene-producing Bacillus subtilis increased mouse resistance against Salmonella typhimurium infection in a CD36-dependent manner. Front Immunol. 2017;8:483.

65. Farache J, Koren I, Milo I, Gurevich I, Kim KW, Zigmond E, Furtado GC, Lira SA, Shakhar G. Luminal bacteria recruit CD103+ dendritic cells into the intestinal epithelium to sample bacterial antigens for presentation. Immunity. 2013;38:581-95.

66. Vincent IE, Balmelli C, Meehan B, Allan G, Summerfield A, McCullough KC. Silencing of natural interferon producing cell activation by porcine circovirus type 2 DNA. Immunology. 2007;120:47-56.

67. Tsuji M, Suzuki K, Kinoshita K, Fagarasan S. Dynamic interactions between bacteria and immune cells leading to intestinal lgA synthesis. Semin Immunol. 2008;20:59-66.

68. Brandtzaeg P. Mucosal immunity: induction, dissemination, and effector functions. Scand J Immunol. 2009;70:505-15.

69. Göbel T, Stangassinger M. NK and T cells constitute two major, functionally distinct intestinal epithelial lymphocyte subsets in the chicken. Int Immunol. 2001;13:757.

70. Myers TJ, Schat KA. Natural killer cell activity of chicken intraepithelial leukocytes against rotavirus-infected target cells. Vet Immunol Immunopathol. 1990;26:157-70.

71. Tamauchi H, Yoshida Y, Sato T, Hachimura S, Inoue M, Kaminogawa S, Habu S. Oral antigen induces antigen-specific activation of intraepithelial CD4+ lymphocytes but suppresses their activation in spleen. Immunobiology. 2005;210:709-21.

72. Wang R-F, Peng G, Wang HY. Regulatory T cells and toll-like receptors in tumor immunity. Semin Immunol. 2006;18:136-42.

73. Sakaguchi S, Setoguchi R, Yagi H, Nomura T. Naturally Arising Foxp3Expressing CD25+CD4+ Regulatory T Cells in Self-Tolerance and Autoimmune Disease. In: Radbruch A, Lipsky PE, editors. Current Concepts in Autoimmunity and Chronic Inflammation. Berlin, Heidelberg: Springer Berlin Heidelberg; 2006. p. 51-66.

74. Xu XG, Zhao HN, Zhang Q, Ding L, Li ZC, Li W, Wu HY, Chuang KP, Tong DW, Liu HJ. Oral vaccination with attenuated Salmonella enterica serovar Typhimurium expressing cap protein of PCV2 and its immunogenicity in mouse and swine models. Vet Microbiol. 2012;157:294-303.

75. Lahiri A, Das $P$, Chakravortty D. Engagement of TLR signaling as adjuvant: towards smarter vaccine and beyond. Vaccine. 2008;26:6777-83.

76. Akira S. Toll-like receptors and innate immunity. Biochem Biophys Res Commun. 2009;388:621-5.

77. Uenishi H, Shinkai H. Porcine toll-like receptors: the front line of pathogen monitoring and possible implications for disease resistance. Dev Comp Immunol. 2009;33:353-61.

78. Zhang E, Lu M. Toll-like receptor (TLR)-mediated innate immune responses in the control of hepatitis B virus (HBV) infection. Med Microbiol Immunol. 2015;204:11-20. 
79. Thompson AJ, Locarnini SA. Toll-like receptors, RIG--like RNA helicases and the antiviral innate immune response. Immunol Cell Biol. 2007:85:435-45.

80. Huang JM, Hong HA, Van TH, Hoang TH, Brisson A, Cutting SM. Mucosal delivery of antigens using adsorption to bacterial spores. Vaccine. 2010;28: 1021-30.

81. Tunis MC, Marshall JS. Toll-like receptor 2 as a regulator of oral tolerance in the gastrointestinal tract. Mediat Inflamm. 2014;2014:606383.

\section{Publisher's Note}

Springer Nature remains neutral with regard to jurisdictional claims in published maps and institutional affiliations.

Ready to submit your research? Choose BMC and benefit from:

- fast, convenient online submission

- thorough peer review by experienced researchers in your field

- rapid publication on acceptance

- support for research data, including large and complex data types

- gold Open Access which fosters wider collaboration and increased citations

- maximum visibility for your research: over $100 \mathrm{M}$ website views per year

At $\mathrm{BMC}$, research is always in progress.

Learn more biomedcentral.com/submissions 